\title{
Sistem Peringatan Pada Pengendara Yang Berpapasan Ditikungan Tajam Berbasis Mikrokontroller
}

\author{
Dedi Setiawan \\ STMIK Triguna Dharma
}

\begin{tabular}{ll}
\hline \hline Article Info & ABSTRACT \\
\hline Article history: & Beberapa jalur darat di Indonesia sudah memiliki jalan yang telah \\
Received Jan $30^{\text {th }}, 2018$ & diaspal halus dan bebas dari lubang. Tak heran jika kebanyakan \\
Revised Feb $02^{\text {nd }}, 2018$ & pengendara memilih membawa kendaraan sendiri dan melewati jalur \\
Accepted Feb $07^{\text {th }}, 2019$ & darat saat berkendara. Tapi ternyata, ada beberapa jalur menuju \\
& lokasi yang terbilang ekstem, yaitu berliku dengan tikungan yang \\
& sangat tajam dan cukup berbahaya pada pengendara yang tidak \\
Keyword: & mengetahui medan. Kecelakaan antara mobil atau truk sering terjadi \\
Mikrokontroler & ketika melewati tikungan yang sangat tajam. \\
Loadcell & Sistem ini akan digunakan pada tikungan yang sangat tajam untuk \\
LCD & memberitahukan kepada pengendara yang berpapasan agar dapat \\
& mengetahui jenis kendaraan yang lewat pada tikungan. Cara kerja \\
& dari sistem ini adalah ketika kendaraan melewati sensor loadcell \\
& sebagai inputan dari berat kendaraan maka microcontroller akan \\
& memproses data inputan yang akan ditampilkan LCD akan \\
& menampilkan teks kedalam untuk jenis kendaraan yang melewati \\
& tikungan dan suara menggunakan buzzer agar pengendara lain \\
memberikan jalan kepada kendaraan yang lebih besar untuk lewat \\
terlebih dahulu. Diharapkan sistem ini akan mengurangi resiko \\
terjadinya kecelakaan..
\end{tabular}

Copyright (c) 2019 STMIK Triguna Dharma. All rights reserved.

First Author

Nama: Dedi Setiawan

Kantor : STMIK Triguna Dharma

\section{PENDAHULUAN}

Sejak komputer ditemukan perkembangan dunia teknologi sekarang ini telah merambah kepada berbagai bidang kehidupan dan ilmu pengetahuan. Revolusi komputer juga mengalami dinamika yang cepat baik dari segi ukuran (makro dan mikro komputer), data yang diolah, bidang yang diolah maupun kemampuan komputer dalam mengolah data serta ukuran komputer secara fisik. Berdasarkan kapasitas makro dan mikro komputer dapat diklasifikasikan menjadi beberapa kriteria pengelompok komputer yang terdiri dari microcontroller, microcomputer, engineering workstation, minicomputer, mainframe dan supercomputer. Microcontroller memiliki semua peralatan pokoknya sebagai sebuah komputer dalam satu chip. Peralatan tersebut diantaranya adalah: pemroses (processing), memory dan input dan output. Saat ini mendorong manusia untuk terus berpikir kreatif, tidak hanya menggali penemuan - penemuan baru, tapi juga memaksimalkan kinerja teknologi yang ada untuk meringankan kerja manusia dalam kehidupan sehari-hari seperti pengendalian perangkat elektronik lainnya seperti sistem alarm peringatan otomatis. Sistem ini akan digunakan pada tikungan yang sangat tajam untuk memberitahukan kepada kendaraan yang berpapasan mengetahui jenis kendaraan yang lewat pada tikungan. Cara kerja dari sistem ini adalah menampilkan jenis kendaraan yang melewati tikungan yang dilengkapi dengan sensor load cell ( sensor penghitung berat objek ) agar pengendara lain memberikan jalan kepada kendaraan yang lebih besar untuk lewat terlebih dahulu. Diharapkan sistem ini akan mengurangi resiko terjadinya kecelakaan. 


\section{LANDASAN TEORI}

\subsection{Tikungan}

Tikungan adalah jalan yang berbelok. Beberapa jalur darat di Indonesia sudah memiliki jalan yang telah diaspal halus dan bebas dari lubang. Tak heran jika kebanyakan wisatawan memilih membawa kendaraan sendiri dan melewati jalur darat saat traveling.

Tapi ternyata, ada beberapa jalur menuju lokasi wisata yang terbilang ekstem, yaitu berliku dengan tikungan sangat tajam dan cukup berbahaya yang tidak mengetahui medan. Kecelakaan antara mobil atau truk sering terjadi ketika melewati tikungan yang sangat tajam.

Saat ini mendorong manusia untuk terus berpikir kreatif, tidak hanya menggali penemuan - penemuan baru, tapi juga memaksimalkan kinerja teknologi yang ada untuk meringankan kerja manusia dalam kehidupan sehari-hari seperti pengendalian perangkat elektronik lainnya seperti sistem alarm peringatan otomatis. Sistem ini akan digunakan pada tikungan yang sangat tajam untuk memberitahukan kepada kendaraan yang berpapasan mengetahui jenis kendaraan yang lewat pada tikungan. Cara kerja dari sistem ini adalah menampilkan jenis kendaraan yang melewati tikungan yang dilengkapi dengan sensor load cell ( sensor penghitung berat objek ) agar pengendara lain memberikan jalan kepada kendaraan yang lebih besar untuk lewat terlebih dahulu. Diharapkan sistem ini akan mengurangi resiko terjadinya kecelakaan. Berikut adalah gambar dari tikungan tajam.

\subsection{Mikrokontroler}

Mikrokontroler adalah suatu alat elektronika digital yang mempunyai masukan dan keluaran serta kendali dengan program yang bisa ditulis dan dihapus dengan cara khusus. Sederhana, cara kerja mikrokontroler sebenarnya hanya membaca dan menulis data. Mikrokontroler merupakan komputer didalam chip yang digunakan untuk mengontrol peralatan elektronik, yang menekankan efisiensi dan efektifitas biaya. Secara harfiahnya bisa disebut "pengendali kecil" dimana sebuah sistem elektronik yang sebelumnya banyak memerlukan komponen-komponen pendukung seperti IC TTL dan CMOS dapat direduksi atau diperkecil dan akhirnya terpusat serta dikendalikan oleh mikrokontroler. Namun demikian tidak sepenuhnya mikrokontroler bisa mereduksi komponen IC TTL dan CMOS yang seringkali masih diperlukan untuk aplikasi kecepatan tinggi atau sekedar menambah jumlah saluran masukan dan keluaran (I/O). Dengan kata lain, mikrokontroler adalah versi mini atau mikro dari sebuah komputer karena mikrokontroler sudah mengandung beberapa periferal yang langsung bisa dimanfaatkan, misalnya port paralel, port serial, komparator, konversi digital ke analog (DAC), konversi analog ke digital dan sebagainya hanya menggunakan sistem minimum yang tidak rumit atau kompleks

\subsection{Load Cell}

Load cell adalah suatu alat transducer yang menghasilkan output yang proposional dengan beban atau gaya yang diberikan. Load cell dapat memberikan pengukuran yang akurat dari gaya dan beban. Load cell digunakan untuk mengkonversikan regangan pada logam ke tahanan variabel.

\subsection{Buzzer}

Buzzer adalah sebuah komponen elektronika yang berfungsi untuk mengubah getaran listrik menjadi getaran suara. Pada dasarnya prinsip kerja buzzer hampir sama dengan loud speaker, jadi buzzer juga terdiri dari kumparan yang terpasang pada diafragma dan kemudian kumparan tersebut dialiri arus sehingga menjadi elektromagnet, kumparan tadi akan tertarik ke dalam atau keluar, tergantung dari arah arus dan polaritas magnetnya, karena kumparan dipasang pada diafragma maka setiap gerakan kumparan akan menggerakkan diafragma secara bolak-balik sehingga membuat udara bergetar yang akan menghasilkan suara. Buzzer biasa digunakan sebagai indikator bahwa proses telah selesai atau terjadi suatu kesalahan pada sebuah alat (alarm).

\subsection{Liquid Crystal Display}

LCD (Liquid Crystal Display) adalah suatu jenis media tampil yang menggunakan kristal cair sebagai penampil utama. LCD sudah digunakan diberbagai bidang misalnya alal-alat elektronik seperti televisi, kalkulator, atau pun layar komputer. Pada postingan aplikasi LCD yang dugunakan ialah LCD dot matrik dengan jumlah karakter $2 \times 16$. LCD sangat berfungsi sebagai penampil yang nantinya akan digunakan untuk menampilkan status kerja alat. Mode 8-bit sangat baik digunakan ketika kecepatan menjadi keutamaan dalam sebuah aplikasi dan setidaknya minimal tersedia 11 pin I/O (3 pin untuk kontrol, 8 pin untuk data). Sedangkan mode 4 bit minimal hanya membutuhkan 7-bit ( 3 pin untuk kontrol, 4 pin untuk data). Bit RS digunakan untuk memilih apakah data atau instruksi yang akan ditransfer antara mikrokontroller dan LCD. Jika bit ini di set $(\mathrm{RS}=1)$, maka byte pada posisi kursor LCD saat itu dapat dibaca atau ditulis. Jika bit ini di reset $(\mathrm{RS}=0)$, merupakan instruksi yang dikirim ke LCD atau status eksekusi dari instruksi terakhir yang dibaca. 


\section{PEMBAHASAN DAN HASIL}

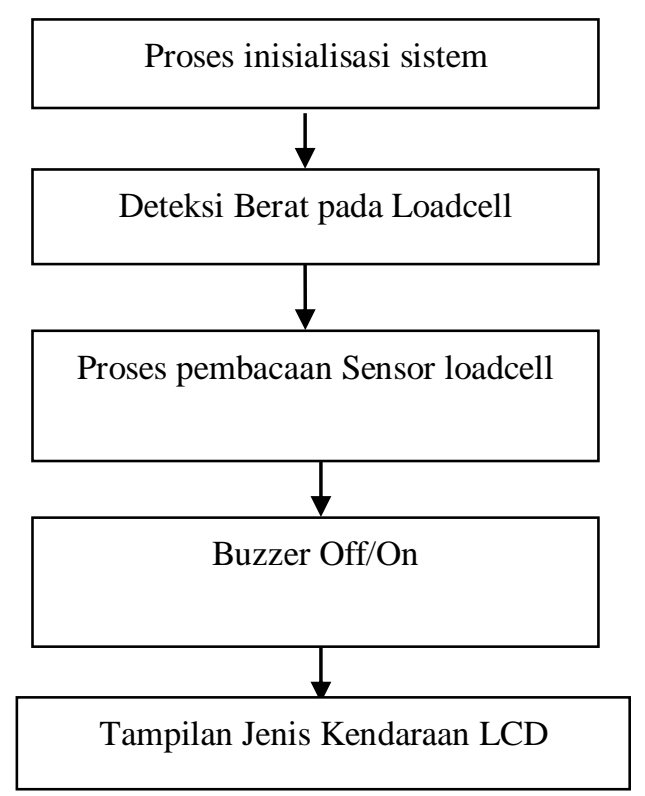

Gambar 1 Algoritma Sistem

Pada gambar merupakan algoritma terhadap permasalahan yang dimulai dari proses inisialisasi yaitu proses pendeteksian perintah awal sebelum melakukan pendeteksian input pada sensor Loadcell. Setelah melakukan proses inisialisasi maka dilakukan pendeteksian pada b berat kendaraan kemudian dilanjutkan dengan proses verifikasi kode inputan atau pembacaan dari sensor loadcell perintah merespon atau tidak. Selanjutnya buzzer dan LCD akan bekerja sesuai fungsinya yang menampilkan jenis berat kendaraan.

Blok diagram sistem adalah diagram yang menggambarkan aliran input hingga output. Diagram ini merupakan konfigurasi sistem, yaitu komponen-komponen yang ada dalam sistem. Input terdiri dari Sensor Ultrasonik, kemudian proses terdiri dari Microcontroller dan output terdiri dari Buzzer dan LCD.

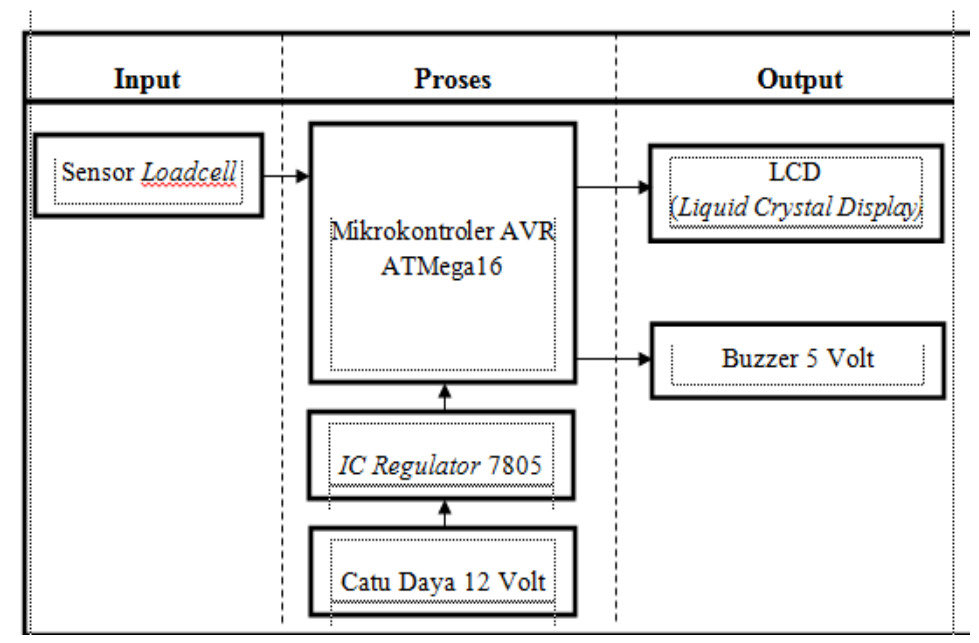

Gambar 2 Blok Diagram

Berdasarkan gambar diatas, dapat dijelaskan fungsi dari setiap masing-masing blok diagram sebagai berikut: 1. Power supplay (adaptor)

Power supplay (Adaptor) berfungsi untuk mengubah besar tegangan dari 220 Volt menjadi 5 Volt langsung ke Arduino

2. Sensor Loadcell 
Sensor Loadcell berfungsi untuk mendeteksi berat kendaraan. Apabila kenderaan melewati sensor maka sensor loadcell akan mengirimkan data ke dalam microcontroller.

3. Microcontroller

Microcontroller berfungsi untuk menerima input dari Sensor Loadcell digunakan sebagai pusat pengendali utama pada rangkaian .

4. Buzzer

Buzzer berfungsi sebagai menunjukkan hasil kerja dari perangkat sistem yang menghasilkan berupa bunyi.

5. LCD

LCD berfungsi sebagai menampilkan teks untuk jenis kendaraan yang terdeteksi oleh sensor loadcell.

Dalam hal ini perancangan fisik alat yang dibuat adalah sketsa sistem peringatan pada kendaraan yang berpapasan pada tikungan tajam dengan menggunakan software Google Sketchup, adapun sketsa dari sistem rancang alat tersebut adalah sebagai berikut:

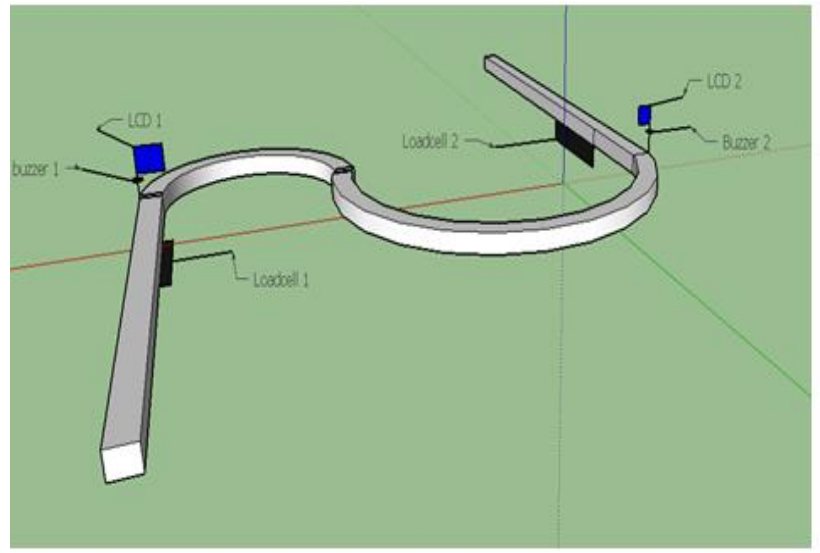

Gambar 3 Rancangan prototype peringatan pada kendaraan di tikungan tajam

Pada gambar diatas merupakan prototype peringatan pada kendaraan di tikungan tajam. Pada posisi ini terlihat beberapa komponen utama pada alat.

1. Microcontroller

2. Buzzer

3. Sensor Loadcell

4. LCD.

Penerapan dari sistem ini Dengan inputan berupa sensor loadcell yang akan mendeteksi apabila loadcell tidak mendeteksi objek kendaraan berat, maka nilai biner nya adalah 0 yaitu buzzer akan off. Nilai 0 hanya berlaku pada buzzer tapi tidak berlaku untuk $L C D, L C D$ akan tetap menyala (mendapatkan nilai 1 dari biner) dan menampilkan pesan untuk mengutamakan keselamatan.

Contoh Algoritma pemograman ketika tidak aktif (biner 0) :

If berat $>10$ and berat $<100$ Then

Lcd "UTAMAKAN KESELAMATAN"

Buzzer $=0$

Keterangan : Buzzer tidak menyala karena tidak ada objek yang terdeteksi.

Contoh Algoritma pemograman ketika aktif (biner 1) :

If berat >100 Then

Lcd "AWAS KENDARAAN BERAT"

Buzzer $=1$

Keterangan : Buzzer akan tetap menyala dan LCD akan menampilkan pesan "AWAS KENDARAAN BERAT" sampai sensor loadcell tidak mendeteksi objek kendaran yang melewati sensor tersebut.

Mikrokontroler yang digunakan dalam rancangan ini adalah jenis AVR yaitu ATMega16 sebanyak satu buah mikrokontroler dan nantinya akan diprogram dengan Software BASCOM-AVR. 


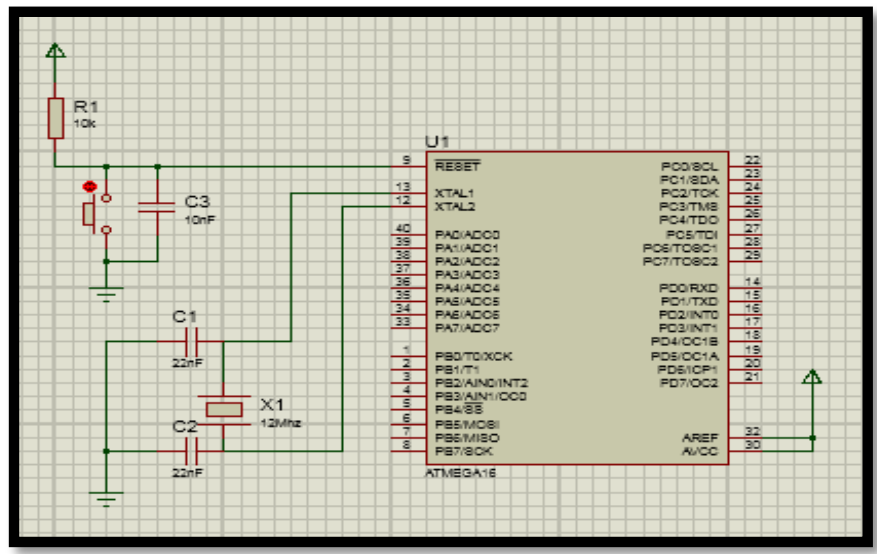

Gambar 4 Rangkaian Sistem Minimum ATMega16

Pada rancangan ini sensor Loadcell digunakan untuk mendeteksi apakah pengendara yang berpapasan pada tikungan terdeteksi dengan jenis kendaraan berat dan kendaraan ringan. Dalam hal ini sensor load cell menggunakan modul hx711 sebagai loadcell amplifier. Berikut gambar dari rangkaian sensor load cell.

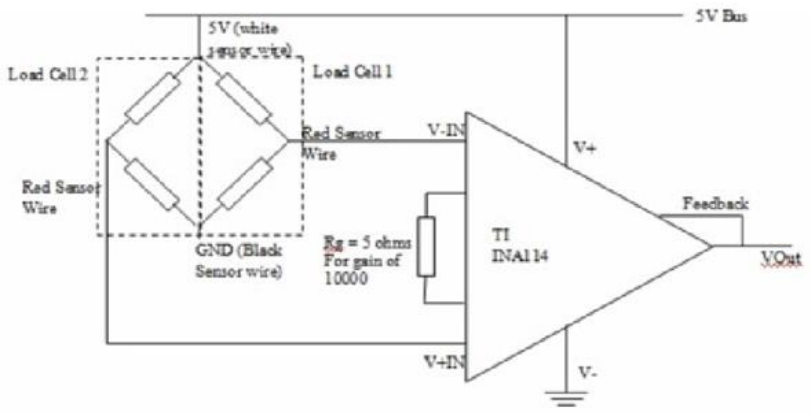

Gambar 5 Rangkaian Sensor Loadcell

Buzzer berfungsi sebagai suara peringatan ketika ada kenderaan yang terdeteksi oleh sensor loadcell dan mengirimkan data kedalam microcontroller yang selanjutnya buzzer akan on bila kendaraan terdeteksi $>100$ maka buzzer akan on dan selain itu buzzer akan off. Sehingga pengendara yang melewati tikungan akan berhenti terlebih dahulu untuk memberikan jalan kepada pengendara lain terutama pengendara jenis kendaraan berat.

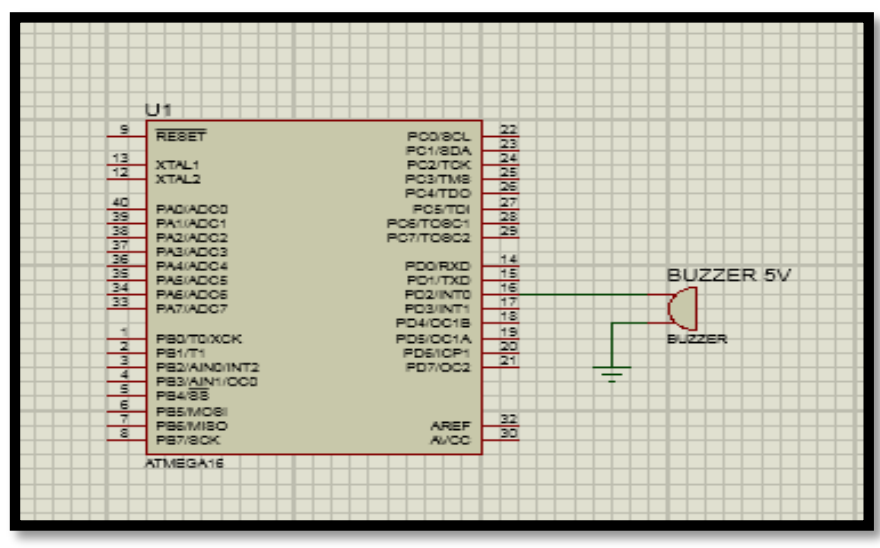

Gambar 6 Rangkaian Buzzer

Rangkaian $L C D$ merupakan rangkaian yang dibuat agar $L C D$ dapat bekerja dan berfungsi dengan semestinya. $L C D$ memiliki $16 \mathrm{kaki} /$ pin ynag masing-masing kakinya dipasang sesuai dengan jalur rangkaian pada mikrokontroler. Pada gambar 12 terlihat $L C D$ sudah di rangkai dengan sempurna, berikut gambar rangkaian dari $L C D 16 \times 2$ yang sudah di sambungkan ke Mikrokontroler. 


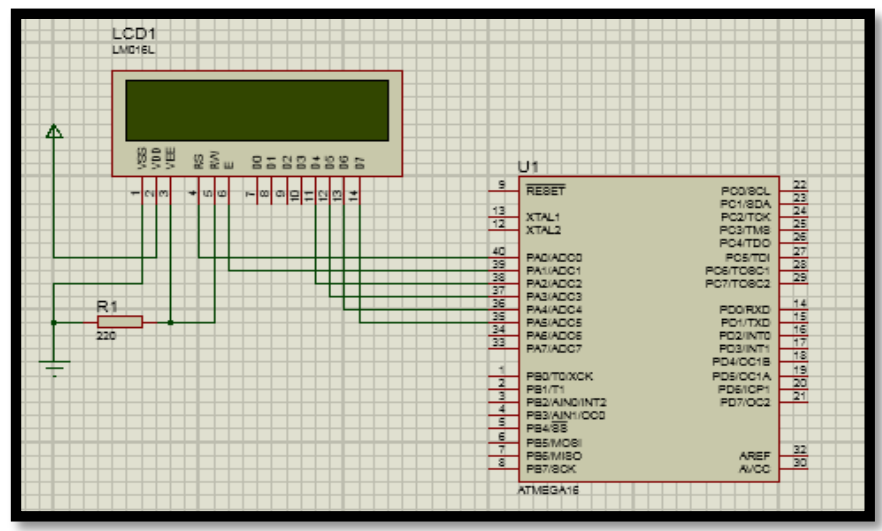

Gambar 7 Rangkaian LCD

Rangkaian regulator tegangan adalah rangkaian pengatur tegangan agar tegangan yang keluar dari rangkaian ini tetap pada satu nilai meskipun inputnya lebih besar dari nilai yang diinginkan. Pada perancangan ini digunakan LM7805 sebagai regulator tegangan dikarenakan LM7805 dapat menerima tegangan masukan antara $8 \mathrm{~V}-18 \mathrm{~V}$ tetapi tegangan keluarannya bernilai $5 \mathrm{~V}$ yang sesuai dengan tegangan yang dibutuhkan oleh mikrokontroler sebagai catu dayanya. Rangkaian tampak seperti pada gambar 12.

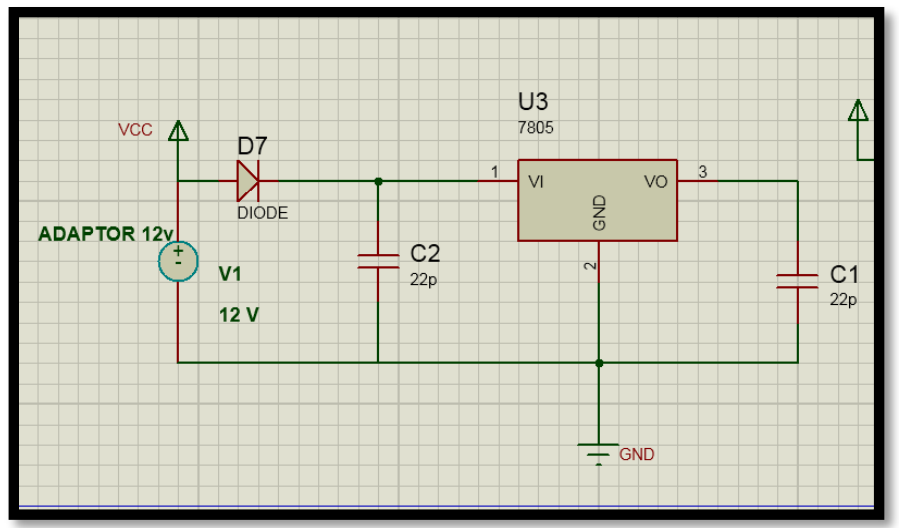

Komponen :

Gambar 8 Rangkaian Catu Daya

1. 2 buah kapasitor $22 \mathrm{pF}$

2. 1 buah dioda (D1)

3. Sebuah Regulator IC 7805

4. Adaptor 12 Volt sebagai catu daya.

\section{KESIMPULAN}

Kesimpulan yang dapat di ambil dari rangkaian dan sistem keseluruhan Prototype sistem pemberithuan jenis kendaraan yang berpapasan pada tikungan secara otomatis dengan menggunaan berbasis microcontroller adalah sebagai berikut:

1. Didalam rancangan sistem pemberithuan jenis kendaraan yang berpapasan pada tikungan secara otomatis avr ATmega 16 sebagai pemroses input dan output

2. Didalam rancangan sistem pemberithuan jenis kendaraan yang berpapasan pada tikungan secara otomatis avr ATmega 16 menggunakan load cell untuk mendeteksi berat kendaraan yang melintasi.

3. Cara kerja dari alat ini adalah mendeteksi jenis kendaraan dengan memberikan indicator peringatan berupa buzzer dan jenis kendaraan kedalam LCD $16 * 2$.

\section{REFERENSI}

[1] http://dasarelektronika.com/pengertian dan fungsi/

[2] http://www.produksieletronika.com/2013/10/cara-prinsip-kerja-sensor/

[3] http://digilib.mercubuana.ac.id/

[4] Kadir. Abdul, 2013, PENGENALAN ALGORITMA, Yogyakarta; CV;Andi Offset.

[5] Team work STMIK TRIGUNA DHARMA, 2014 Workshop TA/Skripsi,Medan. 